\title{
Quantifying the magnitude of a missing hydroxyl radical source in a tropical rainforest
}

\author{
L. K. Whalley ${ }^{1,2}$, P. M. Edwards ${ }^{1}$, K. L. Furneaux ${ }^{1, \dagger}$, A. Goddard ${ }^{1}$, T. Ingham ${ }^{1,2}$, M. J. Evans ${ }^{3}$, D. Stone ${ }^{1}$, \\ J. R. Hopkins ${ }^{4,5}$, C. E. Jones ${ }^{4,5}$, A. Karunaharan ${ }^{6}$, J. D. Lee ${ }^{4,5}$, A. C. Lewis ${ }^{4,5}$, P. S. Monks ${ }^{6}$, S. J. Moller ${ }^{4}$, and \\ D. E. Heard ${ }^{1,2}$ \\ ${ }^{1}$ School of Chemistry, University of Leeds, Woodhouse Lane, Leeds, LS2 9JT, UK \\ ${ }^{2}$ National Centre for Atmospheric Science, University of Leeds, Leeds, LS2 9JT, UK \\ ${ }^{3}$ School of Earth and Environment, University of Leeds, Woodhouse Lane, Leeds, LS2 9JT, UK \\ ${ }^{4}$ Chemistry Department, University of York, Heslington, YO10 5DD, UK \\ ${ }^{5}$ National Centre for Atmospheric Science, University of York, Heslington, YO10 5DD, UK \\ ${ }^{6}$ Department of Chemistry, University of Leicester, University Road, Leicester, LE1 7RH, UK \\ ${ }^{\dagger}$ Sadly passed away on 28 July 2009
}

Received: 2 February 2011 - Published in Atmos. Chem. Phys. Discuss.: 17 February 2011

Revised: 18 July 2011 - Accepted: 19 July 2011 - Published: 22 July 2011

\begin{abstract}
The lifetime of methane is controlled to a very large extent by the abundance of the $\mathrm{OH}$ radical. The tropics are a key region for methane removal, with oxidation in the lower tropical troposphere dominating the global methane removal budget (Bloss et al., 2005). In tropical forested environments where biogenic VOC emissions are high and $\mathrm{NO}_{\mathrm{x}}$ concentrations are low, $\mathrm{OH}$ concentrations are assumed to be low due to rapid reactions with sink species such as isoprene. New, simultaneous measurements of $\mathrm{OH}$ concentrations and $\mathrm{OH}$ reactivity, $k_{\mathrm{OH}}^{\prime}$, in a Borneo rainforest are reported and show much higher $\mathrm{OH}$ than predicted, with mean peak concentrations of $\sim 2.5 \times 10^{6}$ molecule $\mathrm{cm}^{-3}$ (10 min average) observed around solar noon. Whilst $j\left(\mathrm{O}^{1} \mathrm{D}\right)$ and humidity were high, low $\mathrm{O}_{3}$ concentrations limited the $\mathrm{OH}$ production from $\mathrm{O}_{3}$ photolysis. Measured $\mathrm{OH}$ reactivity was very high, peaking at a diurnal average of $29.1 \pm 8.5 \mathrm{~s}^{-1}$, corresponding to an $\mathrm{OH}$ lifetime of only $34 \mathrm{~ms}$. To maintain the observed $\mathrm{OH}$ concentration given the measured $\mathrm{OH}$ reactivity requires a rate of $\mathrm{OH}$ production approximately 10 times greater than calculated using all measured $\mathrm{OH}$ sources. A test of our current understanding of the chemistry within a tropical rainforest was made using a detailed zero-dimensional model to compare with measurements. The model overpredicted the observed $\mathrm{HO}_{2}$ concentrations and significantly under-predicted $\mathrm{OH}$ concentrations. Inclusion of an additional $\mathrm{OH}$ source formed as a recycled product of $\mathrm{OH}$ ini-
\end{abstract}

Correspondence to: L. K. Whalley (l.k.whalley@leeds.ac.uk) tiated isoprene oxidation improved the modelled $\mathrm{OH}$ agreement but only served to worsen the $\mathrm{HO}_{2}$ model/measurement agreement. To replicate levels of both $\mathrm{OH}$ and $\mathrm{HO}_{2}$, a process that recycles $\mathrm{HO}_{2}$ to $\mathrm{OH}$ is required; equivalent to the $\mathrm{OH}$ recycling effect of $0.74 \mathrm{ppbv}$ of NO. This recycling step increases $\mathrm{OH}$ concentrations by $88 \%$ at noon and has wide implications, leading to much higher predicted $\mathrm{OH}$ over tropical forests, with a concomitant reduction in the $\mathrm{CH}_{4}$ lifetime and increase in the rate of VOC degradation.

\section{Background}

$\mathrm{OH}$ radicals are responsible for the removal of the majority of reactive trace gases emitted into the atmosphere (Heard and Pilling, 2003; Monks, 2005). In remote, background environments, far from anthropogenic emissions, $\mathrm{OH}$ is primarily produced by the photolysis of $\mathrm{O}_{3}$ and the subsequent reaction of $\mathrm{O}\left({ }^{1} \mathrm{D}\right)$ atoms with $\mathrm{H}_{2} \mathrm{O}$ vapour:

$\mathrm{O}_{3} \stackrel{h v(<340 \mathrm{~nm})}{\longrightarrow} \mathrm{O}\left({ }^{1} \mathrm{D}\right)+\mathrm{O}_{2}$

$\mathrm{O}\left({ }^{1} \mathrm{D}\right)+\mathrm{H}_{2} \mathrm{O} \rightarrow 2 \mathrm{OH}$

The photolysis of other trace gases, for example HONO and $\mathrm{H}_{2} \mathrm{O}_{2}$ can also act as direct $\mathrm{OH}$ sources. Reactions of $\mathrm{O}_{3}$ with alkenes may contribute to $\mathrm{OH}$ formation in the daytime and these reactions may be a significant source of the radical at night in the absence of photolytic sources (Salisbury et al., 2001). In the presence of $\mathrm{NO}, \mathrm{HO}_{2}$ can also be recycled back

Published by Copernicus Publications on behalf of the European Geosciences Union. 
to $\mathrm{OH}$. In contrast to these relatively few well defined $\mathrm{OH}$ sources, in all but the cleanest of background environments there are a multitude of $\mathrm{OH}$ sinks, and, due to the large variety of these, it becomes virtually impossible to measure each explicitly. In tropical rainforests, the emissions of highly reactive biogenic VOCs are large. Global modelling studies estimate that such biogenic emissions may significantly reduce the oxidising capacity in tropical forests (Lelieveld et al., 2002; Lelieveld et al., 2004), and, in turn, extend the lifetime of $\mathrm{CH}_{4}$ in these areas considerably. In contrast to model predictions, field studies in mid-latitude forests (Carslaw et al., 2001; Tan et al., 2001), and more recently in tropical rainforests (Lelieveld et al., 2008; Butler et al., 2008; Kubistin et al., 2010; Martinez et al., 2010) and other tropical locations (Hofzumahaus et al., 2009) have found that appreciable concentrations of $\mathrm{OH}$ are maintained even in the presence of high biogenic emissions indicating that $\mathrm{OH}$ sources are not properly captured by models under certain chemical conditions.

Thornton et al. (2002) first suggested that uncertainties in the product of the branching ratio and/or rate constant for organic peroxide formation from $\mathrm{HO}_{2}+\mathrm{RO}_{2}$ reactions could be a cause for large modelled/measured $\mathrm{OH}$ discrepancies. Lelieveld et al. (2008) extended this idea, proposing that the source of unpredicted $\mathrm{OH}$ over Amazonia may derive from the reaction of $\mathrm{HO}_{2}$ with organic peroxy radicals (formed via isoprene oxidation) directly forming $\mathrm{OH}$. In support of this, several studies have highlighted that the modelled/measured discrepancy increases as a function of isoprene (Ren et al., 2008; Kubistin et al., 2010). Modelling studies suggest that between 2 to $3.2 \mathrm{OH}$ radicals need to be recycled from these reactions to reproduce the $\mathrm{OH}$ mixing ratios measured over Amazonia (Butler et al., 2008; Kubistin et al., 2010). However, kinetic studies of reactions of $\mathrm{HO}_{2}$ with a number of peroxy radicals do not support such high $\mathrm{OH}$ yields (Hasson et al., 2004; Dillon and Crowley, 2008).

A number of novel mechanisms that provide a significant yield of $\mathrm{OH}$ following the $\mathrm{OH}$ initiated oxidation of isoprene have recently been reported, determined by theoretical $a b$ initio calculations (Peeters et al., 2009; Da Silva et al., 2010; Nguyen et al., 2010) or by laboratory studies (Paulot et al., 2009). The mechanism of Peeters et al. (2009) postulates an $\mathrm{OH}$ radical yield of $\sim 1$ per isoprene molecule oxidised; more recent publications (Stravrakou et al., 2010; Peeters \& Muller, 2010) assume that an $\mathrm{OH}$ yield of up to 3 may be possible and, as such, has the greatest potential to sustain the oxidising capacity in rainforests. Calculations suggest that if an $\mathrm{OH}$ yield of 3 from isoprene oxidation were to be included in the MECCA modelling scheme used in the GABRIEL project, the $\mathrm{OH}$ model under-prediction could be rectified (Peeters et al., 2009; Archibald et al., 2010; Stavrakou et al., 2010). During the PRIDE-PRD campaign, Hofzumahaus et al. (2009) excluded additional $\mathrm{HO}_{\mathrm{x}}$ initiation pathways, as their inclusion in model calculations caused an overestimation in the previously well replicated $\mathrm{HO}_{2}$ concentra- tions. Instead, Hofzumahaus et al. (2009) proposed that the additional $\mathrm{OH}$ source could derive from the recycling of $\mathrm{RO}_{2}$ radicals to $\mathrm{HO}_{2}$ and subsequently of $\mathrm{HO}_{2}$ radicals to $\mathrm{OH}$ via reaction with unidentified species. A similar observation was also made by Tan et al. (2001) during the PROPHET 98 campaign, in which the measured $\mathrm{OH}$ concentrations were, on average, a factor of 2.7 times greater than modelled concentrations, whilst the $\mathrm{HO}_{2}$ modelled and measured concentrations were in reasonable agreement, suggesting a missing process converting $\mathrm{HO}_{2}$ to $\mathrm{OH}$ rather than a missing direct $\mathrm{OH}$ source.

Pugh et al. (2010) have used the Cambridge tropospheric trajectory model of chemistry and transport (CiTTyCAT) (Wild et al., 1996) to assess the chemistry of the Borneo rainforest during the Oxidants and Particle Photochemical Processes (OP3) project and suggest a reduction of $50 \%$ in the effective rate coefficient for reaction of $\mathrm{OH}$ with isoprene (caused by incomplete mixing of isoprene-rich air-parcels) is able to resolve the underestimation of $\mathrm{OH}$ whilst maintaining agreement between measured isoprene, MVK and MACR concentrations and isoprene fluxes. However, more recently the degree of isoprene $\mathrm{OH}$ separation was determined to be no greater than $15 \%$ (Pugh et al., 2011).

In this paper, we make use of measurements of $\mathrm{OH}, \mathrm{HO}_{2}$, $\mathrm{OH}$ reactivity and ancillary species and radiation parameters that are involved in the production of $\mathrm{OH}$, to investigate the closure of the $\mathrm{HO}_{\mathrm{x}}$ budget and make a first quantitative assessment of the magnitude of unrepresented sources. All data reported in this paper were recorded during the OP3 project that took place in the Malaysian Borneo rainforest (Hewitt et al., 2010).

\section{Experimental}

Measurements were performed during the OP3 field campaign (Hewitt et al., 2010) in 2008 at Bukit Atur Global Atmospheric Watch station $\left(5.0^{\circ} \mathrm{N}, 117.8^{\circ} \mathrm{E}\right)$, in Danum Valley, located in the Sabah region of the Borneo rainforest. The campaign consisted of two intensive four week measurement periods run during April (OP3-I) and July (OP3-III); OH reactivity measurements were made during the April intensive only. Co-located measurements of VOCs (measured using Gas Chromatography-Flame Ionisation Detection, Hopkins et al., 2003), $\mathrm{O}_{3}$ (UV absorption, Martin et al., 2006), NO, $\mathrm{NO}_{2}$ (chemiluminescence and photolytic converter, Martin et al., 2006), $j\left(\mathrm{O}^{1} \mathrm{D}\right)$ (filter radiometry, Bohn et al., 2008), $\mathrm{OH}$ (Fluorescence Assay by Gas Expansion - details below) and $\mathrm{OH}$ reactivity (details below) were made in a forest clearing from the roof of a $6 \mathrm{~m}$ (length) shipping container located on a flat-bed trailer, at a height of approximately $5 \mathrm{~m}$. The surrounding tree tops were at a height of $\sim 10 \mathrm{~m}$ and the container was located $\sim 10 \mathrm{~m}$ from the forest edge. The measurement inlets for $\mathrm{OH}$ and $\mathrm{OH}$ reactivity were in full sunlight from approximately 06:00-18:00 local time (LT). The sum 
of $\mathrm{HO}_{2}+\mathrm{RO}_{2}$ were detected at a height of $\sim 5 \mathrm{~m}$ using the PEroxy Radical Chemical Amplification (PERCA) technique (Fleming et al., 2006), from the roof of a second shipping container displaced $\sim 20 \mathrm{~m}$ from the $\mathrm{OH}$ measurement container. The measurement of the sum of $\mathrm{HO}_{2}+\mathrm{RO}_{2}$ has been used to assess the potential importance of an $\mathrm{OH}$ source from reaction of $\mathrm{RO}_{2}$ radicals with $\mathrm{HO}_{2}$ radicals. A rate coefficient, $k_{\mathrm{HO}_{2}+\mathrm{RO}_{2}}=2.05 \times 10^{-13} \mathrm{e}^{(1300 / T)} \mathrm{cm}^{3}$ molecule $\mathrm{e}^{-1} \mathrm{~s}^{-1}$ which is the Master Chemical Mechanism (MCM) recommendation for reaction of isoprene derived peroxy radicals with $\mathrm{HO}_{2}$, is used in these calculations.

A number of measurements used in the Photostationary Steady State (PSS) analyses (Sect. 3) were limited or missing during the April intensive, in some cases data taken during the second measurement period have been utilised to provide an estimate of typical values of these species in this environment. For example, such an approach has been employed for $\mathrm{HO}_{2}$ concentration measurements, which were not made during the first measurement period owing to the unavailability of nitric oxide gas to convert $\mathrm{HO}_{2}$ to $\mathrm{OH}$ for subsequent detection. The average diurnal profile of $\mathrm{HO}_{2}$ measured during OP3-III was used in the PSS. $j\left(\mathrm{O}^{1} \mathrm{D}\right)$ was measured from the roof of the $\mathrm{OH}$ measurement container using a filter radiometer (Bohn et al., 2008) throughout both intensives. Similar peak photolysis rates were observed during both measurement periods although increased cloud cover during the second campaign led to more frequent brief reductions in $j\left(\mathrm{O}^{1} \mathrm{D}\right)$. The photolysis rates of other species such as $j$ (peroxides) have been calculated using the Tropospheric Ultraviolet and Visible (TUV) radiation model (Madronich and Flocke, 1998). The correlation between TUV calculated $j$ (peroxides) with TUV calculated $j\left(\mathrm{O}^{1} \mathrm{D}\right)$ was determined allowing these photolysis rates to be scaled to the measured $j\left(\mathrm{O}^{1} \mathrm{D}\right)$ values to account for passing clouds. The presence of clouds is likely to affect the photolysis rates of these chemical species by different amounts adding an additional uncertainty into the calculations performed. No peroxide measurements were made during either intensive period. A constant concentration in the PSS analyses has been assumed for $\mathrm{H}_{2} \mathrm{O}_{2}$ and organic peroxides (we have assumed that the total organic peroxides are all $\mathrm{CH}_{3} \mathrm{OOH}$ ) of $2.41 \mathrm{ppbv}$ and $0.96 \mathrm{ppbv}$, respectively, which represent measured concentrations of these species that were made in the boundary layer over Amazonia during the GABRIEL campaign (Lelieveld et al., 2008). The $\mathrm{OH}$ yield of 0.26 from $\mathrm{O}_{3}$-isoprene reactions was taken from recent recommendations (Malkin et al., 2010).

HONO was not measured during OP3-I; low concentrations of HONO (peak concentration was $\sim 15$ pptv, Pugh et al., 2011) were detected during OP3-III, however. At these mixing ratios, the photolysis of HONO has a negligible impact as an $\mathrm{OH}$ source and, as such, is not included in the results presented on this paper.

\section{1 $\mathrm{OH}$ and $\mathrm{HO}_{2}$ measurements}

$\mathrm{OH}$ was measured using the fluorescence assay by gas expansion (FAGE) technique, and details of the experimental arrangement can be found in Whalley et al. (2010). Air was drawn into a large cylindrical, stainless steel cell via a $1 \mathrm{~mm}$ diameter nozzle sat upon a $5 \mathrm{~cm}$ tall turret. The cell was maintained at 0.9 Torr. The $\mathrm{OH}$ radicals were electronically excited at $\sim 308 \mathrm{~nm}$ using a tuneable, pulsed laser. The fluorescence at the same wavelength was detected perpendicular to the laser axis using a channel photo-multiplier (CPM) and gated photon counting. The sensitivity of the cell towards $\mathrm{OH}$ was calibrated using VUV photolysis of $\mathrm{H}_{2} \mathrm{O}$ vapour in a flow of zero air, coupled to $\mathrm{O}_{2}$ actinometry, to generate a known quantity of $\mathrm{OH}$ radicals. Data were collected every $10 \mathrm{~s}$ and then averaged up to the $10 \mathrm{~min}$ radical concentrations presented here. The average limit of detection (LOD) of the system during the campaign was $\sim 1.95$ $\times 10^{5}$ molecule $\mathrm{cm}^{-3}$ (10 min data collection period), with an associated uncertainty due to the accuracy of the calibration of $\sim 15 \%(1 \sigma) . \quad \mathrm{HO}_{2}$ may also be detected using the FAGE technique by first titrating $\mathrm{HO}_{2}$ to $\mathrm{OH}$ by the addition of small quantities $(\sim 30 \mathrm{sccm})$ of NO $(99.5 \%$, BOC) above the excitation region and this method was employed to detect $\mathrm{HO}_{2}$ during the second intensive. The $\mathrm{HO}_{2}$ measurements made in OP3-III and used in the subsequent analysis are taken during periods when local $\mathrm{NO}_{\mathrm{x}}$ concentrations were not elevated from natural background levels.

\subsection{OH reactivity}

$\mathrm{OH}$ reactivity $\left(k_{\mathrm{OH}}^{\prime}\right)$ was measured using an apparatus which has been described in detail by Ingham et al. (2009). Ambient air was drawn into a $2 \mathrm{~m}$ long, $10 \mathrm{~cm}$ internal diameter PVC flow tube at a rate of $300 \mathrm{~L} / \mathrm{min}$, generating a turbulent flow. $\mathrm{OH}$ was generated by $185 \mathrm{~nm}$ photolysis of $\mathrm{H}_{2} \mathrm{O}$ vapour in a $\mathrm{N}_{2}$ flow and introduced into the flow tube via a sliding injector, and was detected downstream in the flowtube using a second FAGE cell. Increasing the distance (and, therefore, time, $t$ as the flow-velocity was known) between the point of injection and the FAGE sampling point enables the decay of $\mathrm{OH}$ to be recorded, which was found to be exponential and is described by:

$[\mathrm{OH}]_{t}=[\mathrm{OH}]_{0} e^{\left(-\left(k_{\mathrm{OH}}^{\prime}+k_{\text {physical }}^{\prime}\right) t\right)}$

where $k_{\text {physical }}^{\prime}=6.1 \pm 0.65 \mathrm{~s}^{-1}$ is the physical $\mathrm{OH}$ loss rate. $k_{\text {physical }}^{\prime}$ was determined post-campaign by replacing the ambient air flow with an extremely clean flow of gas and recording the subsequent decay (P. M. Edwards, personal communication, 2011). 


\subsection{Box model incorporating the Master Chemical Mechanism}

The Dynamically Simple Model of Atmospheric Chemical Complexity (DSMACC) zero-dimensional box model (Stone et al., 2010) has been used to estimate $\mathrm{HO}_{2}$ concentrations for comparison with the ambient $\mathrm{HO}_{2}$ concentrations measured during OP3-III. The chemistry scheme, generated by the Master Chemical Mechanism (Carslaw et al., 2001), includes near explicit degradation schemes for the observed hydrocarbons, isoprene, $\alpha$-pinene, $\mathrm{C}_{2} \mathrm{H}_{6}$, $\mathrm{C}_{2} \mathrm{H}_{4}, \mathrm{C}_{3} \mathrm{H}_{8}, \mathrm{C}_{3} \mathrm{H}_{6}, i \mathrm{C}_{4} \mathrm{H}_{10}, n-\mathrm{C}_{4} \mathrm{H}_{10} i-\mathrm{C}_{5} \mathrm{H}_{12}, n-\mathrm{C}_{5} \mathrm{H}_{12}$, $n-\mathrm{C}_{6} \mathrm{H}_{14}$ and $\mathrm{C}_{2} \mathrm{H}_{2}$. Rate coefficients for inorganic reactions and three body reactions were updated to recent recommendations. Simulations were integrated forwards using a Rosenbrock solver (Hairer and Wanner, 1991) with a timestep of $600 \mathrm{~s}$ until a diurnal steady state was reached, at which point the diurnal cycles of simulated species were considered to exhibit less than $0.01 \%$ variation from day to day.

Simulations were constrained to the observed average diurnal cycles of $\mathrm{O}_{3}, \mathrm{NO}, \mathrm{NO}_{\mathrm{x}}, \mathrm{CO}, \mathrm{H}_{2} \mathrm{O}$ vapour, $j\left(\mathrm{O}^{1} \mathrm{D}\right)$, temperature and the observed hydrocarbons listed above for all days of OP3-I, averaged into $30 \mathrm{~min}$ time bins. The modelled $\mathrm{HO}_{2}$ was compared to one day of $\mathrm{HO}_{2}$ measurements taken during OP3-III. This day was chosen for comparison with the model as the concentrations of auxiliary measurements on this day were similar to the measurement values used as model constraints. The mean total peroxy radicals $\left(\mathrm{HO}_{2}+\mathrm{RO}_{2}\right)$ concentrations, as detected using the PERCA method (Fleming et al., 2006), were similar during OP3-I and OP3-III supporting the assumption that the OP3-I $\mathrm{HO}_{2}$ concentrations were likely similar to the $\mathrm{HO}_{2}$ concentrations recorded during OP3-III. $\mathrm{NO}_{2}$ and total $\mathrm{NO}_{\mathrm{x}}$ were the only constrained species permitted to vary during each $24 \mathrm{~h}$ period in the model with their concentrations constrained in such a way as to constrain the $\mathrm{NO}_{2}$ to its observed value at the end of each $24 \mathrm{~h}$ period in the model whilst maintaining the modelled partitioning between $\mathrm{NO}_{\mathrm{x}}$ species. $\mathrm{NO}$ was constrained to its observed concentration at the beginning of the model run and then permitted to vary with the constraints placed on $\mathrm{NO}_{2}$ and total $\mathrm{NO}_{\mathrm{x}}$. This approach has been employed previously by Ren et al. (2008) and Stone et al. (2010). The methane concentration in the model was set to $1770 \mathrm{ppbv}$ and the hydrogen concentration was set to $550 \mathrm{ppbv}$ (Novelli et al., 1999; Ehhalt and Rohrer, 2009).

Photolysis rates, except for $j\left(\mathrm{O}^{1} \mathrm{D}\right)$, which was measured, were calculated using the tropospheric ultraviolet and visible (TUV) radiation model at solar zenith angles (SZA) between 0 and $90^{\circ}$ in $5^{\circ}$ steps. Spline fits were applied to the calculated photolysis rates as a function of SZA, and the appropriate photolysis rates selected for the SZA. Calculated photolysis rates were subsequently scaled to the mean ratio of TUV calculated and observed $j\left(\mathrm{O}^{1} \mathrm{D}\right)$. A surface albedo of 0.1 (Govaerts et al., 2008) was used for all model runs.
In order to prevent the build-up of long-lived unconstrained species such as $\mathrm{H}_{2} \mathrm{O}_{2}$ and other peroxides in the model, a deposition lifetime was applied to all calculated species, to represent physical loss of species either through deposition or mixing. As there are no observations of these species to allow a true deposition rate to be estimated, a rate coefficient for the deposition process of $1 \times 10^{-5} \mathrm{~s}^{-1}$ was chosen for all runs presented here, corresponding to a deposition lifetime of $24 \mathrm{~h}$; the modelled $\mathrm{HO}_{2}$ concentration increases by $14 \%$ if the deposition lifetime increases to $48 \mathrm{~h}$. The sensitivity of the model to this parameter is further discussed by Stone et al. (2010).

\section{Results and discussion}

The average diurnal profile, constructed from 25 days of $\mathrm{OH}$ measurements during the first OP3 campaign (OP3-I), and shown in Fig. 1, is used in all subsequent analyses. The $1 \sigma$ standard deviation of this averaged profile is mainly due to the variability of the data from day-to-day caused by variability in chemical composition, but also contains a contribution from instrumental precision. The corresponding average diurnal profiles of $\mathrm{NO}, \mathrm{O}_{3}, j\left(\mathrm{O}^{1} \mathrm{D}\right)$, isoprene and $\mathrm{OH}$ reactivity, $k_{\mathrm{OH}}^{\prime}$, all of which influence the $\mathrm{OH}$ profile, are also shown in Fig. 1 for the OP3-I campaign. The mean daytime isoprene concentration of $\sim 1.9 \mathrm{ppbv}$ (averaged between 06:00 18:00 LT) measured during OP3-I is comparable to isoprene measurements made in the boundary layer over the Suriname rainforest during the GABRIEL project (mean daytime isoprene $\sim 2$ ppbv observed, Lelieveld et al., 2008). Only $2 \mathrm{~h}$ of $\mathrm{OH}$ reactivity data were taken during the GABRIEL project due to an instrument failure making it difficult to compare the mean diurnal levels. Peak OH reactivities, however, were similar (72 $\pm 18 \mathrm{~s}^{-1}$ and $83.6 \pm 26.0 \mathrm{~s}^{-1}$ (single points)) during GABRIEL (Sinha et al., 2008) and OP3 respectively. NO concentrations are also similar ( $\sim 0.02 \mathrm{ppbv})$ to those measured during the GABRIEL project (Lelieveld et al., 2008) at all times other than at sunrise when a reproducible spike in NO peaking at $\sim 0.2 \mathrm{ppbv}$ was observed during the OP3 project (Fig. 1); please refer to Pike et al. (2010) for further details on the OP3-I NO profile. Both $\mathrm{O}_{3}$ concentration and $\mathrm{O}_{3}$ photolysis rates were higher over the Suriname forest $\left(\mathrm{O}_{3} \sim 18.5 \mathrm{ppbv}\right.$, mean daytime concentration and $j\left(\mathrm{O}^{1} \mathrm{D}\right)$ $\sim 6.3 \times 10^{-5} \mathrm{~s}^{-1}$ at solar noon, Martinez et al., 2010) than in the Borneo forest (Fig. 1) indicating that the rate of primary production of $\mathrm{OH}$ from the photolysis of $\mathrm{O}_{3}$ and subsequent reaction with $\mathrm{H}_{2} \mathrm{O}$ vapour was higher during the GABRIEL project than OP3. The factor of two difference in noontime $j\left(\mathrm{O}^{1} \mathrm{D}\right)$ between OP3 and GABRIEL is surprising given the similar latitudes of the two field projects. The lower $j\left(\mathrm{O}^{1} \mathrm{D}\right)$ observed during $\mathrm{OP} 3$ may be partially explained by cloud-cover and measurement height, i.e. ground observations (OP3) vs aircraft measurements (GABRIEL). It is likely also that the proximity of the surrounding trees 

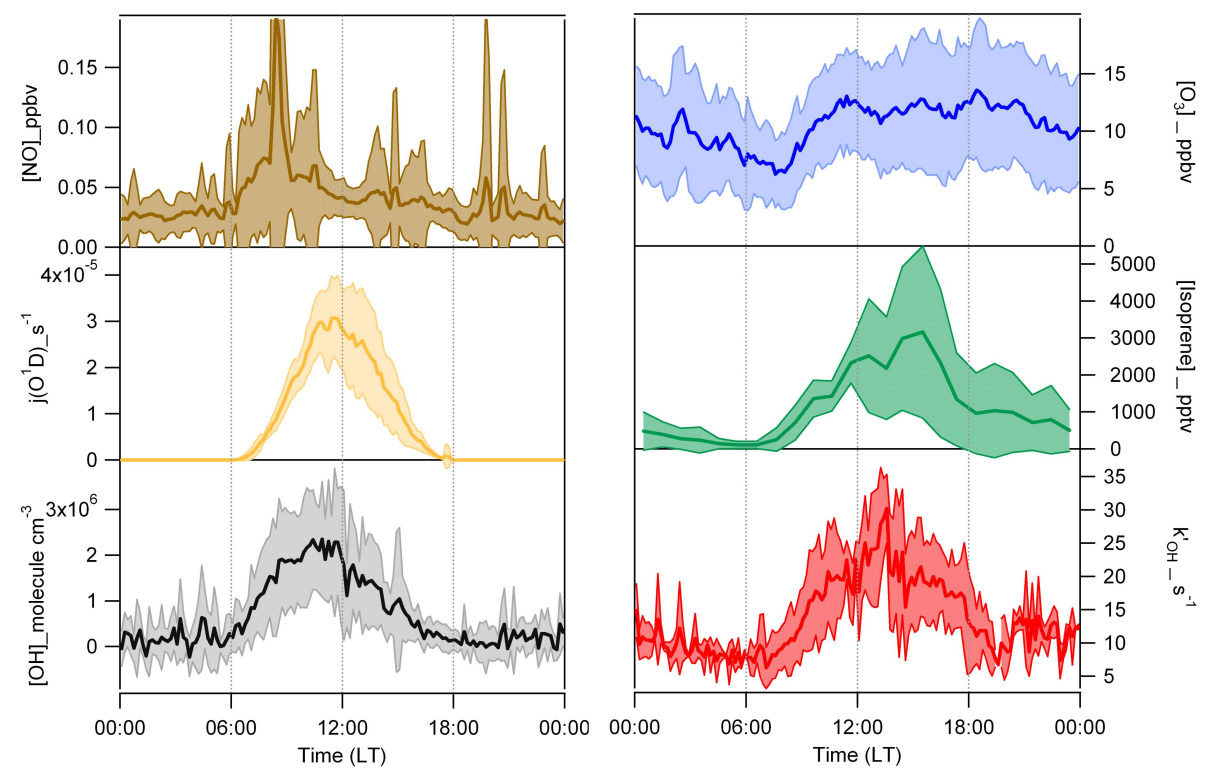

Fig. 1. Average diurnal profile of key species during OP3-I generated from 10 min data taken over 25 days (from the 6 April $2008-2$ May 2008) for $\mathrm{OH}, k_{\mathrm{OH}}^{\prime}, j\left(\mathrm{O}^{1} \mathrm{D}\right), \mathrm{NO}$ and $\mathrm{O}_{3}$, and over 25 days from hourly data for isoprene. The shaded areas show the $1 \sigma$ day-to-day variability of the data used to generate the mean diurnal profiles.

Table 1. Description of the scenarios used in the text and figures and the impact of the different OH source terms in the PSS approximation Eq. (4). The colours of the lines in the symbol column correspond to the $[\mathrm{OH}]_{\text {calc }}$ diurnal profile shown in Fig. 2 calculated using the different Scenarios $(1-5) .[\mathrm{OH}]_{\text {calc. }}:[\mathrm{OH}]_{\text {meas }}$ ratio represents the mean ratio over $24 \mathrm{~h}$ for all scenarios apart from Scenario $4 . f$ is the fraction of $\mathrm{O}\left({ }^{1} \mathrm{D}\right)$ that reacts with $\mathrm{H}_{2} \mathrm{O}$ vapour to form $\mathrm{OH}$, rather than being quenched to $\mathrm{O}\left({ }^{3} \mathrm{P}\right)$.

\begin{tabular}{|c|c|c|c|}
\hline Scenario & $\Sigma_{\mathrm{OH}_{\text {sources }}}$ & Symbol (Fig. 2) & $\frac{[\mathrm{OH}]_{\text {calc }}}{[\mathrm{OH}]_{\text {meas }}}$ \\
\hline (1) & $2 j\left(\mathrm{O}^{1} \mathrm{D}\right)\left[\mathrm{O}_{3}\right]\left[\mathrm{H}_{2} \mathrm{O}\right] f$ & - & 0.05 \\
\hline (2) & $\begin{array}{l}(1)+k_{\mathrm{NO}}+\mathrm{HO}_{2}\left[\mathrm{HO}_{2}\right][\mathrm{NO}]+\mathrm{k}_{\mathrm{O}_{3}}+\mathrm{HO}_{2}\left[\mathrm{O}_{3}\right]\left[\mathrm{HO}_{2}\right]+0.26 k_{\mathrm{O}_{3}}+\mathrm{C}_{5} \mathrm{H}_{8}\left[\mathrm{O}_{3}\right]\left[\mathrm{C}_{5} \mathrm{H}_{8}\right]+ \\
2 j\left(\mathrm{H}_{2} \mathrm{O}_{2}\right)\left[\mathrm{H}_{2} \mathrm{O}_{2}\right]+j\left(\mathrm{CH}_{3} \mathrm{OOH}\right)[\mathrm{ROOH}]\end{array}$ & - & 0.15 \\
\hline (3) & $(2)+k_{\mathrm{C}_{5} \mathrm{H}_{8}+\mathrm{OH}}\left[\mathrm{C}_{5} \mathrm{H}_{8}\right][\mathrm{OH}]$ & - & 0.37 \\
\hline (4) & $(2)+2.7 \times k_{\mathrm{C}_{5} \mathrm{H}_{8}}+\mathrm{OH}\left[\mathrm{C}_{5} \mathrm{H}_{8}\right][\mathrm{OH}]$ & - & $1.0^{*}$ \\
\hline (5) & $(2)+k \mathrm{X}+\mathrm{HO}_{2}[\mathrm{X}]\left[\mathrm{HO}_{2}\right]([\mathrm{X}]=0.74 \mathrm{ppbv})$ & - & 1.0 \\
\hline
\end{tabular}

$*[\mathrm{OH}]_{\text {calc. }}:[\mathrm{OH}]_{\text {meas. }}=1$ during afternoon and evening hours only (noon-midnight).

may have reduced the actinic flux at the Bukit Atur site somewhat. Comparison of the $j\left(\mathrm{O}^{1} \mathrm{D}\right)$ measurements made using the filter radiometer and a spectral radiometer (deployed during OP3iii) were is excellent agreement, providing confidence that the photolysis rates used in the subsequent calculations are accurate. The higher primary rate of production experienced during GABRIEL likely results in the higher daytime mean $\mathrm{OH}$ concentrations observed during the project $\left(\sim 5.6 \times 10^{6}\right.$ molecule $\left.\mathrm{cm}^{-3}\right)$ than during OP3 $\left(\sim 1.2 \times 10^{6}\right.$ molecule $\left.\mathrm{cm}^{-3}\right)$ (Fig. 1). One of the most notable results from the $\mathrm{OP} 3$ project is that significant $\mathrm{OH}$ concentrations are maintained despite a high $\mathrm{OH}$ reactivity, defined by $k_{\mathrm{OH}}^{\prime}=\Sigma k_{\mathrm{OH}+\mathrm{Y}}^{\prime}[\mathrm{Y}]$, where $\mathrm{Y}$ represents an $\mathrm{OH}$ sink, suggesting that there are significant $\mathrm{OH}$ sources present.
The short lifetime of $\mathrm{OH}$ (daytime mean of $\sim 59 \mathrm{~ms}$, Fig. 1) indicates that $\mathrm{OH}$ exists in a photostationary steady state, where $\mathrm{OH}$ production is balanced by $\mathrm{OH}$ loss. Simultaneous measurements of $\mathrm{OH}$ concentration and $k_{\mathrm{OH}}^{\prime}$ enable "measurement" of the total rate of $\mathrm{OH}$ production, $\Sigma_{\mathrm{OH}_{\text {sources }}}$ using:

$\Sigma_{\mathrm{OH}_{\text {sources }}}=[\mathrm{OH}] \times k_{\mathrm{OH}}^{\prime}$

In many environments the major source of $\mathrm{OH}$ is from the reaction of $\mathrm{O}\left({ }^{1} \mathrm{D}\right)$ with water vapour, the rate of which is given by:

$p(\mathrm{OH})=2 \times j\left(O^{1} D\right) \times\left[\mathrm{O}_{3}\right] \times\left[\mathrm{H}_{2} \mathrm{O}\right] \times f$

where $f$ is the fraction of $\mathrm{O}\left({ }^{1} \mathrm{D}\right)$ that reacts with $\mathrm{H}_{2} \mathrm{O}$ vapour to form $\mathrm{OH}$, rather than being quenched to $\mathrm{O}\left({ }^{3} \mathrm{P}\right)$. Although 


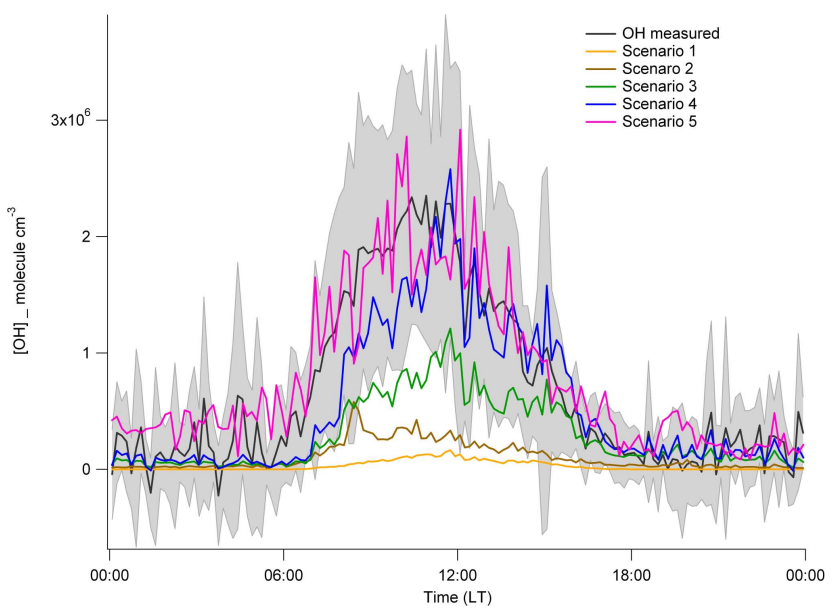

Fig. 2. A comparison of the measured mean diurnal $[\mathrm{OH}]$ profile $\left([\mathrm{OH}]_{\text {meas. }}\right.$ ) (black line) with $[\mathrm{OH}]_{\text {calc. calculated using the PSS }}$ approximation (Eq. 4) constrained to measured $\mathrm{OH}$ reactivity $\left(k_{\mathrm{OH}}^{\prime}\right)$ for the loss term and with various $\mathrm{OH}$ source terms included - see text and Table 1 for further details on the different scenarios. The grey shading represents the $1 \sigma$ standard deviation of the averaged $\mathrm{OH}$ profile, caused primarily by variability of the data from dayto-day due to changing atmospheric conditions, but also contains a contribution from instrumental precision.

$j\left(\mathrm{O}^{1} \mathrm{D}\right)$ and $\mathrm{H}_{2} \mathrm{O}$ vapour concentrations were large, as expected in the tropics (peak $j\left(\mathrm{O}^{1} \mathrm{D}\right) \sim 3 \times 10^{-5} \mathrm{~s}^{-1}$ on average and $\left.\left[\mathrm{H}_{2} \mathrm{O}\right] \sim 2.5 \% \mathrm{v} / \mathrm{v}\right), p(\mathrm{OH})$ was limited by the low $\mathrm{O}_{3}$ concentrations observed (peak $\left[\mathrm{O}_{3}\right] \sim 11 \mathrm{ppbv}$ ). If it is assumed that $p(\mathrm{OH})$ represents the only source of $\mathrm{OH}$, i.e. $\Sigma_{\mathrm{OH}_{\text {sources }}}=p(\mathrm{OH})($ Scenario 1 , Table 1), then the $\mathrm{OH}$ concentration, calculated by rearrangement of Eq. (2):

$[\mathrm{OH}]_{\text {calc. }}=\frac{\Sigma_{\mathrm{OH}_{\text {sources }}}}{k_{\mathrm{OH}}^{\prime}}$

would be expected to be very low given to the high value of $k_{\mathrm{OH}}^{\prime}$. Figure 2 shows a comparison of the average diurnal measured $\mathrm{OH}$ concentration $\left([\mathrm{OH}]_{\text {meas }}\right)$ and $[\mathrm{OH}]_{\text {calc. }}$; $[\mathrm{OH}]_{\text {calc }}$ under-predicts $[\mathrm{OH}]_{\text {meas }}$ by a factor of $\sim 20$ at noon. As $k_{\mathrm{OH}}^{\prime}$ is measured (representing all $\mathrm{OH}$ sinks), the comparison shows that significant additional $\mathrm{OH}$ sources must be present in addition to production of $\mathrm{OH}$ from the reaction $\mathrm{O}\left({ }^{1} \mathrm{D}\right)+\mathrm{H}_{2} \mathrm{O}$ Eq. (3). Figure 2 also shows $[\mathrm{OH}]_{\text {calc }}$ when all known $\mathrm{OH}$ sources are incorporated in Eq. (4), as detailed in Eq. (5). $\left(\mathrm{C}_{5} \mathrm{H}_{8}=\right.$ isoprene) (Scenario 2, Table 1) (see Sect. 2 for further details on any estimates made on unmeasured species included in Eq. 5):

$$
\begin{aligned}
& \Sigma_{\mathrm{OH}_{\text {sources }}}=p(\mathrm{OH})+k_{\mathrm{NO}+\mathrm{HO}_{2}}\left[\mathrm{HO}_{2}\right][\mathrm{NO}]
\end{aligned}
$$

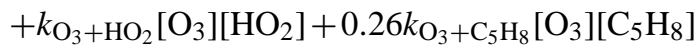

$$
\begin{aligned}
& +2 j\left(\mathrm{H}_{2} \mathrm{O}_{2}\right)\left[\mathrm{H}_{2} \mathrm{O}_{2}\right]+j\left(\mathrm{CH}_{3} \mathrm{OOH}\right)[\mathrm{ROOH}]
\end{aligned}
$$

$[\mathrm{OH}]_{\text {calc }}$ increases, predominantly due to inclusion of an $\mathrm{OH}$ source from $\mathrm{HO}_{2}+\mathrm{NO}(78 \%$ of the increase is due to inclusion of $\mathrm{HO}_{2}+\mathrm{NO}$ ) despite $\mathrm{NO}$ concentrations being very low; this $\mathrm{OH}$ source has the biggest impact on the PSS calculation during the early morning hours when NO peaks at $\sim 200 \mathrm{pptv}$. Approximately $16 \%$ of $[\mathrm{OH}]_{\text {calc }}$ in Eq. (5) may be attributed to the photolysis of peroxides. Doubling the peroxide concentration increases the peak $[\mathrm{OH}]_{\text {calc }}$ from $3.0 \times 10^{5}$ molecule $\mathrm{cm}^{-3}$ to $3.5 \times 10^{5}$ molecule $\mathrm{cm}^{-3}$; halving the concentration reduces $[\mathrm{OH}]_{\text {calc }}$ to $2.75 \times 10^{5}$ molecule $\mathrm{cm}^{-3}$. Any uncertainties associated with the treatment of the photolysis of the peroxides, therefore, will only have a small impact on $[\mathrm{OH}]_{\text {calc }}$ and do not alter the major findings from this work. Even with the inclusion of all known $\mathrm{OH}$ sources, $[\mathrm{OH}]_{\text {calc }}$ still significantly under-predicts $[\mathrm{OH}]_{\text {meas }}$ (by a factor of 10 at noon), demonstrating that there is still a large, uncharacterised $\mathrm{OH}$ source.

Recent theoretical calculations (Peeters et al., 2009; Da Silva et al., 2010) and laboratory studies (Paulot et al., 2009) have shown that $\mathrm{OH}$ may be regenerated during the $\mathrm{OH}$ initiated oxidation of isoprene under low $\mathrm{NO}_{\mathrm{x}}$ conditions, and if these are included as $\mathrm{OH}$ sources, (Scenario 3, Table 1) $\Sigma_{\mathrm{OH}_{\text {sources }}}$ becomes:

$$
\begin{aligned}
& \Sigma_{\mathrm{OH}_{\text {sources }}}=p(\mathrm{OH})+k_{\mathrm{NO}+\mathrm{HO}_{2}}\left[\mathrm{HO}_{2}\right][\mathrm{NO}] \\
& +k_{\mathrm{O}_{3}+\mathrm{HO}_{2}}\left[\mathrm{O}_{3}\right]\left[\mathrm{HO}_{2}\right]+0.26 \mathrm{k}_{\mathrm{O}_{3}+\mathrm{C}_{5} \mathrm{H}_{8}}\left[\mathrm{O}_{3}\right]\left[\mathrm{C}_{5} \mathrm{H}_{8}\right] \\
& +2 j\left(\mathrm{H}_{2} \mathrm{O}_{2}\right)\left[\mathrm{H}_{2} \mathrm{O}_{2}\right]+j\left(\mathrm{CH}_{3} \mathrm{OOH}\right)[\mathrm{ROOH}] \\
& +\alpha k_{\mathrm{OH}_{+} \mathrm{C}_{5} \mathrm{H}_{8}}[\mathrm{OH}]\left[\mathrm{C}_{5} \mathrm{H}_{8}\right]
\end{aligned}
$$

where $\alpha$ is the recycled yield of $\mathrm{OH}$ following the $\mathrm{OH}$ reaction with isoprene. $[\mathrm{OH}]_{\text {calc }}$ increases considerably if $\alpha=1$ as suggested by Peeters et al. (2009) is used (Scenario 3, Table 1) (Fig. 2), for which there is a direct $\mathrm{OH}$ source $(0.03)$ and a larger $\mathrm{OH}$ source $(0.97)$ from the rapid photolysis of photo-labile co-products and subsequent photochemistry. This mechanism also suggests an appreciable yield of $\mathrm{HO}_{2}(0.7)$. Even with this new, considerable $\mathrm{OH}$ yield of 1 from $\mathrm{OH}$ initiated isoprene oxidation, $\mathrm{OH}$ concentrations are still under-predicted by $\sim 63 \%$ at midday. To achieve $[\mathrm{OH}]_{\text {calc }} /[\mathrm{OH}]_{\text {meas }}=1$ during the afternoon and evening, approximately $2.7 \mathrm{OH}$ radicals would need to be produced per isoprene molecule oxidised ( $\alpha=2.7$, Scenario 4, Table 1), potentially indicating that the $\mathrm{OH}$ yield from isoprene may actually be greater than 1 . Stravrakou et al. (2010) propose that the rapid photolysis of the co-products formed during isoprene oxidation may actually yield $3 \mathrm{OH}$ radicals. It should be noted, however, that $\mathrm{OH}$ concentrations are still under-predicted during the morning even with a yield of 2.7 from isoprene oxidation, as the isoprene concentrations are lower at this time, suggesting that the diurnal profile of the missing $\mathrm{OH}$ source(s) does not entirely follow the isoprene concentration profile. A similar finding has recently been reported by Lu et al. (2011) who found during analysis of $\mathrm{HO}_{\mathrm{x}}$ observations made during the PRIDE-PRD campaign that a dependence of the missing $\mathrm{OH}$ source upon isoprene could 
not be strictly concluded. It is possible that similar mechanisms may also occur during the oxidative degradation of other biogenic species, for example mono-terpenes. A small subset of mono-terpenes were measured during the project; the concentrations of these species are insufficient to reconcile the missing $\mathrm{OH}$ source, however. High concentrations of unmeasured mono-terpenes would have had to be present in addition to those measured if these species are to account for the remaining missing $\mathrm{OH}$ source. P. M. Edwards (personal communication, 2011) found that model simulations of the $\mathrm{OH}$ reactivity measured during the campaign are able to reproduce the general trend in the observations, with the correlation between observed and calculated $\mathrm{OH}$ reactivity giving a linear correlation coefficient of $R=0.9$; but the model under-predicts the magnitude of the observations by $\sim 53 \%$. Although the direct reaction of $\mathrm{OH}$ with isoprene only accounts for $\sim 25 \%$ of the total $\mathrm{OH}$ reactivity, the oxygenated VOCs generated from isoprene oxidation, account for a further $12 \%$ of the reactivity; this fraction increases further (to $\sim 27 \%$ ) if the model is constrained to the $\mathrm{OH}$ observations and further still if the deposition lifetime of the oxygenated VOCs is increased from 1 to 3 days (to $\sim 55 \%$ ). Under this third scenario the model is able to reproduce the magnitude of the reactivity observations to within $4 \%$. These findings demonstrate the importance of the unconstrained oxidation products of the observed biogenic VOCs on $\mathrm{OH}$ reactivity and highlight that any uncertainties in the isoprene oxidation mechanism has the potential to impact modelled $\mathrm{OH}$ concentrations greatly; missing primarily emitted biogenics are not necessarily required to reconcile the observed $\mathrm{OH}$ reactivity.

The effect of including different $\mathrm{OH}$ sources on the calculated $\mathrm{HO}_{2}$ concentration has been investigated using a full modelling approach (see Sect. 2.3), the results of which are shown in Fig. 3. Fuchs et al. (2011) have recently reported an interference in $\mathrm{HO}_{2}$ measurements using a similar instrument as described in this paper. The interference, caused by the partial chemical conversion of certain $\mathrm{RO}_{2}$ species to $\mathrm{OH}$ on addition of NO in the FAGE detection cell, has the potential to cause a systematic positive bias in $\mathrm{HO}_{2}$ measurements and, therefore, $\mathrm{HO}_{2}$ observations reported using the FAGE technique may be higher than the true ambient $\mathrm{HO}_{2}$ concentrations. Under the operating conditions employed during the OP3 campaign, the University of Leeds FAGE instrument was relatively insensitive to detection of $\mathrm{RO}_{2}$ species. During the campaign only one fluorescence cell was used to make alternate measurements of $\mathrm{OH}$ and $\mathrm{HO}_{2}$ and conditions were optimised to maximise its sensitivity to $\mathrm{OH}$. Under this configuration incomplete mixing of NO into the ambient airstream for the $\mathrm{HO}_{2}$ titration was evident and resulted in low conversion of $\mathrm{HO}_{2}$ to $\mathrm{OH}$. Coupled with the high pumping capacity and, therefore, fast gas throughput of the fluorescence cell, this configuration effectively minimised the potential interference from ambient $\mathrm{RO}_{2}$ species. Recent laboratory tests have revealed a $12 \%$ yield of $\mathrm{HO}_{2}$ due to the decomposition of ethene-derived $\mathrm{RO}_{2}$ in the presence of $\mathrm{NO}$

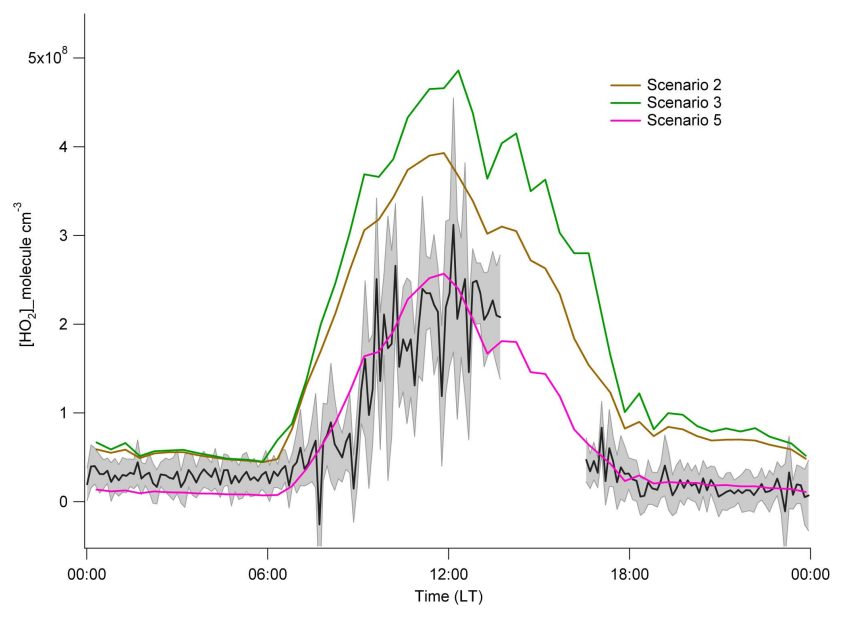

Fig. 3. A comparison of the measured diurnal $\mathrm{HO}_{2}$ concentration profile from one day during OP3-III (black line) (grey shading highlights the $1 \sigma$ variation in $10 \mathrm{~s} \mathrm{HO}_{2}$ signal that has been averaged to generate each 10 min data point) with modelled $\mathrm{HO}_{2}$ from the MCM constrained to measurements made during OP3-I. The brown line represents the modelled $\mathrm{HO}_{2}$ with $\mathrm{OH}$ sources defined by Scenario 2 (Table 1). The green line represents the modelled $\mathrm{HO}_{2}$ with an additional $\mathrm{OH}$ and $\mathrm{HO}_{2}$ source from including the Peeters mechanism (Scenario 3, Table 1). The pink line includes the standard $\mathrm{OH}$ source chemistry with an additional $\mathrm{HO}_{2}$ to $\mathrm{OH}$ cycling step (equivalent to adding an additional $0.74 \mathrm{ppbv}$ of $\mathrm{NO}$ ) in the model (Scenario 5, Table 1).

in the FAGE detection cell under OP3 conditions. This provides an upper limit to the $\mathrm{HO}_{2}$ yield from $\mathrm{RO}_{2}$ species during OP3 as, under conditions optimised to maximise the interference signal, ethene-derived $\mathrm{RO}_{2}$ species provided the largest $\mathrm{HO}_{2}$ yield compared with other $\mathrm{RO}_{2}$ species tested such as those derived from isoprene (yield of $10 \%$ ), and higher alkanes (Whalley, 2011). Model simulations suggest that up to $2.1 \times 10^{8}$ molecule $\mathrm{cm}^{-3}$ of potentially interfering $\mathrm{RO}_{2}$ species were present at solar noon during OP3 and thus up to $2.5 \times 10^{7}$ molecule $\mathrm{cm}^{-3}$ of the $\mathrm{HO}_{2}$ concentration may be attributed to these species $\left(\sim 10 \%\right.$ of the total $\mathrm{HO}_{2}$ signal). This small interference falls within the uncertainty of the $\mathrm{HO}_{2}$ observations and should have very little impact on the following results:

A base run (brown line, Fig. 3) corresponding to all the $\mathrm{OH}$ sources that are included in Eq. (5), excluding any recycled $\mathrm{OH}$ from isoprene, overestimates the $\mathrm{HO}_{2}$ observations taken during OP3-III (taking into account the small $\mathrm{HO}_{2}$ interference would only serve to further increase this over-estimation). $\mathrm{OH}$ concentrations are significantly underpredicted by this model. Inclusion of the Peeters's mechanism (Peeters et al., 2009), which generates $\sim 1 \mathrm{OH}$ radical and $\sim 0.7 \mathrm{HO}_{2}$ radicals per isoprene molecule oxidised leads to a considerable increase in the modelled $\mathrm{HO}_{2}$ concentration ( $\sim 20 \%$ at noon) both as a consequence of an additional primary $\mathrm{HO}_{2}$ source and an increase from VOC and 
$\mathrm{CO}$ oxidation by $\mathrm{OH}$. This mechanism causes the model to further over-predict the measured $\mathrm{HO}_{2}$ concentration (green line, Fig. 3). This model still underestimates $\mathrm{OH}$ and, in line with the PSS calculation (and other modelling studies, e.g. Stavrakou et al., 2010), an $\mathrm{OH}$ yield from isoprene oxidation greater than unity is required to improve the modelled to measured agreement for $\mathrm{OH}$. Such an increase in the $\mathrm{OH}$ yield from this mechanism only serves to increase $\mathrm{HO}_{2}$, reducing the modelled to measured $\mathrm{HO}_{2}$ agreement further. These results are consistent with the findings during the PRIDE-PRD (Hofzumahaus et al., 2009) and PROPHET98 (Tan et al., 2001) campaigns and suggest that if $\mathrm{OH}$ and $\mathrm{HO}_{2}$ are generated during the $\mathrm{OH}$ initiated oxidation of isoprene as postulated by Peeters et al. (2009) an additional mechanism that removes $\mathrm{HO}_{2}$ must also occur to reconcile the measurements.

Hofzumahaus et al. (2009) found that additional recycling of $\mathrm{RO}_{2}$ radicals to $\mathrm{HO}_{2}$ and $\mathrm{HO}_{2}$ to $\mathrm{OH}$ (via an unknown species $\mathrm{X}$ ) could reconcile both $\mathrm{OH}$ and $\mathrm{HO}_{2}$ concentrations during the PRIDE-PDR campaign, and this is incorporated in the rate of $\mathrm{OH}$ production via:

$$
\begin{aligned}
& \Sigma_{\mathrm{OH}_{\text {sources }}}=p(\mathrm{OH})+k_{\mathrm{NO}+\mathrm{HO}_{2}}\left[\mathrm{HO}_{2}\right][\mathrm{NO}] \\
& +k_{\mathrm{O}_{3}+\mathrm{HO}_{2}}\left[\mathrm{O}_{3}\right]\left[\mathrm{HO}_{2}\right]+0.26 k_{\mathrm{O}_{3}+\mathrm{C}_{5} \mathrm{H}_{8}}\left[\mathrm{O}_{3}\right]\left[\mathrm{C}_{5} \mathrm{H}_{8}\right] \\
& +2 j\left(\mathrm{H}_{2} \mathrm{O}_{2}\right)\left[\mathrm{H}_{2} \mathrm{O}_{2}\right]+j\left(\mathrm{CH}_{3} \mathrm{OOH}\right)[\mathrm{ROOH}] \\
& +k_{\mathrm{X}+\mathrm{HO}_{2}}[\mathrm{X}]\left[\mathrm{HO}_{2}\right]
\end{aligned}
$$

To achieve $[\mathrm{OH}]_{\text {calc }} /[\mathrm{OH}]_{\text {meas }}=1$ from an additional $\mathrm{HO}_{2}+\mathrm{X} \rightarrow \mathrm{OH}$ step under OP3 conditions, but without any $\mathrm{OH}$ recycling from isoprene, would require $\sim 0.74 \mathrm{ppbv}$ of unspecified reactant(s) (referred to as $\mathrm{X}$ ) converting $\mathrm{HO}_{2}$ to $\mathrm{OH}$ with the same rate coefficient by reaction with $\mathrm{NO}$ (or a $\mathrm{HO}_{2}$ turnover rate to $\mathrm{OH}$ of $\sim 6.5 \mathrm{~s}$ ) (Scenario 5, Table 1 and Fig. 2). We have also included this additional recycling term in box model calculations of $\mathrm{HO}_{2}$ as shown in Fig. 3 (pink line). Inclusion of the sources of $\mathrm{OH}$ given by Eq. (7) replicates the observed $\mathrm{HO}_{2}$ concentrations well.

The additional recycling of $\mathrm{OH}$ may derive from a $\mathrm{HO}_{2}+\mathrm{RO}_{2}$ reaction as suggested by Lelieveld et al. (2008). However, even if it is assumed that every $\mathrm{RO}_{2}$ radical measured reacts with $\mathrm{HO}_{2}$, a yield of ten $\mathrm{OH}$ radicals on average is required to replicate $\mathrm{OH}$ observations. Such a high $\mathrm{OH}$ radical yield from $\mathrm{RO}_{2}+\mathrm{HO}_{2}$ reactions is not supported by the recent kinetic studies (Hasson et al., 2004; Dillon and Crowley, 2008). Only $\mathrm{RO}_{2}$ radicals which contain a carbonyl functionality adjacent to the peroxy group have been found to regenerate significant $\mathrm{OH}$ upon reaction with $\mathrm{HO}_{2}$ radicals, however, even the yield of $\mathrm{OH}$ from these reactions is only $\sim 0.5$ (Dillon and Crowley, 2008) demonstrating that other major $\mathrm{OH}$ recycling mechanisms must exist in addition to reconcile the $\mathrm{OH}$ concentrations observed.

It is possible that models may be missing both an $\mathrm{OH}$ source mechanism (for example $\mathrm{OH}$ regeneration during isoprene oxidation, Peeters et al., 2009) and a separate $\mathrm{HO}_{2}$ loss mechanism. The fast $\mathrm{HO}_{2}$ turnover rate of just a $\sim 6.5 \mathrm{~s}$ suggests that the unknown $\mathrm{HO}_{2}$ reactant must either be present at reasonable concentrations (e.g. with a reaction rate coefficient equal to $\sim 5 \times 10^{-12} \mathrm{~cm}^{3}$ molecule ${ }^{-1} \mathrm{~s}^{-1}$ then $\sim 1.3$ ppbv of reactant would be required) or react extremely rapidly with $\mathrm{HO}_{2}$ (e.g. if $\sim 65$ pptv of reactant was present then a reaction rate coefficient of $\sim 1 \times 10^{-10} \mathrm{~cm}^{3}$ molecule ${ }^{-1} \mathrm{~s}^{-1}$ would be necessary). Although results from recent theoretical (Peeters et al., 2009; Da Silva et al., 2010; Nguyen et al., 2010) and laboratory studies (Dillon and Crowley, 2008) can help to suggest mechanisms that may help to reduce the modelled-measured discrepancy that is observed under high isoprene, low $\mathrm{NO}_{\mathrm{x}}$ conditions, it seems clear that additional novel $\mathrm{OH}$ source mechanisms and $\mathrm{HO}_{2}$ sink mechanisms are necessary to fully reconcile these recent radical measurements. Lu et al. (2011) draw similar conclusions from work analysing $\mathrm{HO}_{\mathrm{x}}$ observations made in the Pearl river delta in China during the PRIDE-PRD campaign finding that the postulated isoprene mechanisms by Lelieveld et al. (2008) and Peeters and Mueller (2010) alone cannot explain the difference between measured and modelled $\mathrm{OH}$ at low $\mathrm{NO}_{\mathrm{x}}$; inclusion of the Peeters's mechanism was found to lead to an over-prediction of $\mathrm{HO}_{2}$ by $\mathrm{Lu}$ and co-workers also.

\section{Conclusions}

Simultaneous field measurements of $\mathrm{OH}$ concentration, $\mathrm{OH}$ reactivity, and sources/sinks of $\mathrm{OH}$ in the Borneo rainforest at Bukit Atur directly show a large underestimate in $\mathrm{OH}$ sources in tropical forests. Under low $\mathrm{NO}_{\mathrm{x}}$ conditions, an $\mathrm{OH}$ formation route is needed which can be reconciled with both observed $\mathrm{OH}$ and $\mathrm{HO}_{2}$. This work indicates that an additional $\mathrm{OH}$ source from isoprene oxidation cannot resolve both the $\mathrm{OH}$ and $\mathrm{HO}_{2}$ observations at this location unless an additional $\mathrm{HO}_{2}$ sink mechanism is also included. An additional recycling mechanism that converts $\mathrm{HO}_{2}$ to $\mathrm{OH}$ can account for the combined $\mathrm{HO}_{\mathrm{x}}$ observations (without an additional $\mathrm{OH}$ source from isoprene oxidation). The impact of including the additional recycling step as a source of $\mathrm{OH}$ is an $88 \%$ increase in $[\mathrm{OH}]$ at noon, significantly increasing the oxidising capacity of the tropical rainforest, and reducing the lifetime of $\mathrm{CH}_{4}$ in these environments. This work demonstrates that moderate to high $\mathrm{OH}$ concentrations can be sustained in tropical rainforests, despite high biogenic emissions and low ozone, and highlights major uncertainties in the chemical mechanisms currently incorporated in models. Similar conclusions can be drawn from other work in this area. For example, global atmospheric chemistry models (ACMs) are not able to reconcile the observed isoprene concentrations with the measured isoprene emission rates; the emission rates incorporated tend to be lower than estimates based on direct emission measurements (Guenther, 2008). Higher emission rates in ACMs serve to dramatically deplete the $\mathrm{OH}$ radical concentration and lead to unrealistically 
high concentrations of certain key atmospheric constituents (Poisson et al., 2000; Bey et al., 2001) pointing to major uncertainties in the isoprene oxidation mechanism. These uncertainties not only have major implication on the oxidising capacity, but lead to major uncertainties regarding oxidation products and their ultimate fates, e.g. secondary organic aerosol formation. The possibility of previously unidentified isoprene oxidation pathways, such as those discussed in this manuscript, will also undoubtedly impact any top-down estimates of isoprene emissions derived from satellite observations of isoprene oxidation products such as formaldehyde (Shim et al., 2005). This extremely useful approach to determining a global map of isoprene emissions relies heavily on an accurate understanding of isoprene oxidation.

To resolve these uncertainties, laboratory studies to test recently proposed theories are necessary, for example studies focussing on the regeneration of $\mathrm{OH}$ and $\mathrm{HO}_{2}$ during isoprene oxidation or studies to determine $\mathrm{HO}_{2}$ sinks. The ability to speciate individual $\mathrm{RO}_{2}$ species and the measurement of more isoprene oxidation products in future field studies should provide further constraints for models and enable novel oxidation mechanisms to be validated.

Acknowledgements. The authors would like to acknowledge Nick Hewitt and the University of Lancaster OP3 team for help and assistance during the field project. Thanks also to the University of Leeds electronic and mechanical workshops for help with the continued maintenance of the FAGE instrumentation. Acknowledgement is made to the Facility for Ground-based Atmospheric Measurements (FGAM), which is part of the NERC National Centre for Atmospheric Science (NCAS), for provision of the FAGE and GC instruments used in this research. The project was funded by NERC via grant number NE/D002192/1. We thank the Malaysian and Sabah Governments for their permission to conduct research in Malaysia. This is paper number 524 of the Royal Society's South East Asian Rainforest Research Programme.

Edited by: G. McFiggans

\section{References}

Archibald, A. T., Cooke, M. C., Utembe, S. R., Shallcross, D. E., Derwent, R. G., and Jenkin, M. E.: Impacts of mechanistic changes on $\mathrm{HO}_{\mathrm{x}}$ formation and recycling in the oxidation of isoprene, Atmos. Chem. Phys., 10, 8097-8118, doi:10.5194/acp10-8097-2010, 2010.

Bey, I., Jacob, D. J., Yantosca, R. M., Logan, J. A., Field, B. D., Fiore, A. M., Li, Q. B., Liu, H. G. Y., Mickley, L. J., and Schultz, M. G.: Global modeling of tropospheric chemistry with assimilated meteorology: Model description and evaluation, J. Geophys. Res.-Atmos., 106, 23073-23095, 2001.

Bloss, W. J., Evans, M. J., Lee, J. D., Sommariva, R., Heard, D. E., and Pilling, M. J.: The oxidative capacity of the troposphere: Coupling of field measurements of $\mathrm{OH}$ and a global chemistry transport model, Faraday Discuss., 130, 425-436, 2005.

Bohn, B., Corlett, G. K., Gillmann, M., Sanghavi, S., Stange, G., Tensing, E., Vrekoussis, M., Bloss, W. J., Clapp, L. J., Kortner,
M., Dorn, H. P., Monks, P. S., Platt, U., Plass-Dulmer, C., Mihalopoulos, N., Heard, D. E., Clemitshaw, K. C., Meixner, F. X., Prevot, A. S. H., and Schmitt, R.: Photolysis frequency measurement techniques: results of a comparison within the ACCENT project, Atmos. Chem. Phys., 8, 5373-5391, doi:10.5194/acp-85373-2008, 2008.

Butler, T. M., Taraborrelli, D., Fischer, C. B. H., Harder, H., Martinez, M., Williams, J., Lawrence, M. G., and Lelieveld, J.: Improved simulation of isoprene oxidation chemistry with the ECHAM5/MESSy chemistry-climate model: lessons from the GABRIEL airborne field campaign, Atmos. Chem. Phys., 8, 4529-4546, doi:10.5194/acp-8-4529-2008, 2008.

Carslaw, N., Creasey, D. J., Harrison, D., Heard, D. E., Hunter, M. C., Jacobs, P. J., Jenkin, M. E., Lee, J. D., Lewis, A. C., Pilling, M. J., Saunders, S. M., and Seakins, P. W.: $\mathrm{OH}$ and $\mathrm{HO}_{2}$ radical chemistry in a forested region of north-western Greece, Atmos. Environ., 35, 4725-4737, 2001.

Da Silva, G., Graham, C., and Wang, Z.-F.: Unimolecular betahydroxyperoxy radical decompostion with $\mathrm{OH}$ recycling in the photochemical oxidation of isoprene, Environ. Sci. Tech., 44, 250-256, 2010.

Dillon, T. J. and Crowley, J. N.: Direct detection of OH formation in the reactions of $\mathrm{HO}_{2}$ with $\mathrm{CH}_{3} \mathrm{C}(\mathrm{O}) \mathrm{O}_{2}$ and other substituted peroxy radicals, Atmos. Chem. Phys., 8, 4877-4889, doi:10.5194/acp-8-4877-2008, 2008.

Ehhalt, D. H. and Rohrer, F.: The tropospheric cycle of $\mathrm{H}_{2}$ : a critical review, Tellus B - Chem. Phys. Meteorol., 61, 500-535, 2009.

Fleming, Z. L., Monks, P. S., Rickard, A. R., Heard, D. E., Bloss, W. J., Seakins, P. W., Still, T. J., Sommariva, R., Pilling, M. J., Morgan, R., Green, T. J., Brough, N., Mills, G. P., Penkett, S. A., Lewis, A. C., Lee, J. D., Saiz-Lopez, A., and Plane, J. M. C.: Peroxy radical chemistry and the control of ozone photochemistry at Mace Head, Ireland during the summer of 2002, Atmos. Chem. Phys., 6, 2193-2214, doi:10.5194/acp-6-2193-2006, 2006.

Fuchs, H., Bohn, B., Hofzumahaus, A., Holland, F., Lu, K., Nehr, S., Rohrer, F., and Wahner, A.: Detection of $\mathrm{HO}_{2}$ by laserinduced fluorescence: Calibration and interferences from $\mathrm{RO}_{2}$ radicals, Atmos. Meas. Tech., 4, 1209-1225, doi:10.5194/amt-41209-2011, 2011.

Govaerts, Y. M., Lattanzio, A., Taberner, M., and Pinty, B.: Generating global surface albedo products from multiple geostationary satellites, Remote Sens. Environ., 112, 2804-2816, 2008.

Guenther, A.: Atmospheric chemistry: Are plant emissions green?, Nature, 452, 701-702, 2008.

Hairer, E. and Wanner, G.: Solving Ordinary Differential Equations: Stiff and Differential-Algerbraic Problems, Berlin, Germany, 1991.

Hasson, A. S., Tyndall, G. S., and Orlando, J. J.: A product yield study of the reaction of $\mathrm{HO}_{2}$ radicals with ethyl peroxy $\left(\mathrm{C}_{2} \mathrm{H}_{5} \mathrm{O}_{2}\right)$, acetyl peroxy $\left(\mathrm{CH}_{3} \mathrm{C}(\mathrm{O}) \mathrm{O}_{2}\right)$, and acetonyl peroxy $\left(\mathrm{CH}_{3} \mathrm{C}(\mathrm{O}) \mathrm{CH}_{2} \mathrm{O}_{2}\right)$ radicals, J. Phys. Chem. A, 108, 5979-5989, 2004.

Heard, D. E. and Pilling, M. J.: Measurement of $\mathrm{OH}$ and $\mathrm{HO}_{2}$ in the troposphere, Chem. Rev., 103, 5163-5198, 2003

Hewitt, C. N., Lee, J. D., MacKenzie, A. R., Barkley, M. P., Carslaw, N., Carver, G. D., Chappell, N. A., Coe, H., Collier, C., Commane, R., Davies, F., Davison, B., Di Carlo, P., Di Marco, C. F., Dorsey, J. R., Edwards, P. M., Evans, M. J., 
Fowler, D., Furneaux, K. L., Gallagher, M., Guenther, A., Heard, D. E., Helfter, C., Hopkins, J., Ingham, T., Irwin, M., Jones, C., Karunaharan, A., Langford, B., Lewis, A. C., Lim, S. F., MacDonald, S. M., Mahajan, A. S., Malpass, S., McFiggans, G., Mills, G., Misztal, P., Moller, S., Monks, P. S., Nemitz, E., Nicolas-Perea, V., Oetjen, H., Oram, D. E., Palmer, P. I., Phillips, G. J., Pike, R., Plane, J. M. C., Pugh, T., Pyle, J. A., Reeves, C. E., Robinson, N. H., Stewart, D., Stone, D., Whalley, L. K., and Yin, X.: Overview: oxidant and particle photochemical processes above a south-east Asian tropical rainforest (the OP3 project): introduction, rationale, location characteristics and tools, Atmos. Chem. Phys., 10, 169-199, doi:10.5194/acp-10169-2010, 2010.

Hofzumahaus, A., Rohrer, F., Lu, K., Bohn, B., Brauers, T., Chang, C., Fuchs, H., Holland, F., Kita, K., Kondo, Y., Li, X., Lou, S., Shao, M., Zeng, L., Wahner, A., and Zhang, Y.: Amplified trace gas removal in the troposphere, Science, 324, 1702-1704, 2009.

Hopkins, J. R., Lewis, A. C., and Read, K. A.: A two-column method for long-term monitoring of non-methane hydrocarbons (NMHCs) and oxygenated volatile organic compounds (oVOCs) J. Environ. Mon., 5, 8-13, 2003.

Ingham, T., Goddard, A., Whalley, L. K., Furneaux, K. L., Edwards, P. M., Seal, C. P., Self, D. E., Johnson, G. P., Read, K. A., Lee, J. D., and Heard, D. E.: A flow-tube based laser-induced fluorescence instrument to measure $\mathrm{OH}$ reactivity in the troposphere, Atmos. Meas. Tech., 2, 465-477, doi:10.5194/amt-2-465-2009, 2009.

Kubistin, D., Harder, H., Martinez, M., Rudolf, M., Sander, R., Bozem, H., Eerdekens, G., Fischer, H., Gurk, C., Klupfel, T., Konigstedt, R., Parchatka, U., Schiller, C. L., Stickler, A., Taraborrelli, D., Williams, J., and Lelieveld, J.: Hydroxyl radicals in the tropical troposphere over the Suriname rainforest: comparison of measurements with the box model MECCA, Atmos. Chem. Phys., 10, 9705-9728, doi:10.5194/acp-10-97052010, 2010.

Lelieveld, J., Peters, W., Dentener, F. J., and Krol, M. C.: Stability of tropospheric hydroxyl chemistry, J. Geophys. Res. Atmos., 107(D16), 4715, doi:10.1029/2001JD001289, 2002.

Lelieveld, J., Dentener, F. J., Peters, W., and Krol, M. C.: On the role of hydroxyl radicals in the self-cleansing capacity of the troposphere, Atmos. Chem. Phys., 4, 2337-2344, doi:10.5194/acp4-2337-2004, 2004.

Lelieveld, J., Butler, T. M., Crowley, J. N., Dillon, T. J., Fischer, H., Ganzeveld, L., Harder, H., Lawrence, M. G., Martinez, M., Taraborrelli, D., and Williams, J.: Atmospheric oxidation capacity sustained by a tropical forest, Nature, 452, 737-740, 2008.

Lu, K. D., Rohrer, F., Holland, F., Fuchs, H., Bohn, B., Brauers, T., Chang, C. C., Häseler, R., Hu, M., Kita, K., Kondo, Y., Li, X., Lou, S. R., Nehr, S., Shao, M., Zeng, L. M., Wahner, A., Zhang, Y. H., and Hofzumahaus, A.: Observation and modelling of $\mathrm{OH}$ and $\mathrm{HO}_{2}$ concentrations in the Pearl River Delta 2006: a missing $\mathrm{OH}$ source in a VOC rich atmosphere, Atmos. Chem. Phys. Discuss., 11, 11311-11378, doi:10.5194/acpd-11-113112011, 2011.

Madronich, S. and Flocke, S.: Handbook of Environmental Chemistry, edited by: Boule, P., Springer, New York, USA, 1-26, 1998.

Malkin, T. L., Goddard, A., Heard, D. E., and Seakins, P. W.: Measurements of $\mathrm{OH}$ and $\mathrm{HO}_{2}$ yields from the gas phase ozonolysis of isoprene, Atmos. Chem. Phys., 10, 1441-1459, doi:10.5194/acp-10-1441-2010, 2010.

Martin, M. V., Honrath, R. E., Owen, R. C., Pfister, G., Fialho, P., and Barata, F.: Significant enhancements of nitrogen oxides, black carbon, and ozone in the North Atlantic lower free troposphere resulting from North American boreal wildfires, J. Geophys. Res. Atmos., 111, D23S60, doi:10.1029/2006JD007530, 2006.

Martinez, M., Harder, H., Kubistin, D., Rudolf, M., Bozem, H., Eerdekens, G., Fischer, H., Gurk, C., Klupfel, T., Konigstedt, R., Parchatka, U., Schiller, C. L., Stickler, A., Williams, J., and Lelieveld, J.: Hydroxyl radicals in the tropical troposphere over the Suriname rainforest: airborne measurements, Atmos. Chem. Phys., 10, 3759-3773, doi:10.5194/acp-10-3759-2010, 2010.

Monks, P. S.: Gas-phase radical chemistry in the troposphere, Chem. Soc. Rev., 34, 376-395, 2005.

Nguyen, T. L., Vereecken, L., and Peeters, J.: $\mathrm{HO}_{\mathrm{x}}$ Regeneration in the Oxidation of Isoprene III: Theoretical Study of the key Isomerisation of the Z-delta-hydroxy-peroxy Isoprene Radicals, Chem. Phys. Chem., 11, 3996-4001, 2010.

Novelli, P. C., Lang, P. M., Masarie, K. A., Hurst, D. F., Myers, R., and Elkins, J. W.: Molecular hydrogen in the troposphere: Global distribution and budget, J. Geophys. Res. Atmos., 104, 30427-30444, 1999.

Paulot, F., Crounse, J. D., Kjaergaard, H. G., Kurten, A., St Clair, J. M., Seinfeld, J. H., and Wennberg, P. O.: Unexpected Epoxide Formation in the Gas-Phase Photooxidation of Isoprene, Science, 325, 730-733, 2009.

Peeters, J., Nguyen, T. L., and Vereecken, L.: $\mathrm{HO}_{\mathrm{x}}$ radical regeneration in the oxidation of isoprene, Phys. Chem. Chem. Phys., 28, 5935-5939, 2009.

Pike, R. C., Lee, J. D., Young, P. J., Carver, G. D., Yang, X., Warwick, N., Moller, S., Misztal, P., Langford, B., Stewart, D., Reeves, C. E., Hewitt, C. N., and Pyle, J. A.: $\mathrm{NO}_{\mathrm{x}}$ and $\mathrm{O}_{3}^{-}$ above a tropical rainforest: an analysis with a global and box model, Atmos. Chem. Phys., 10, 10607-10620, doi:10.5194/acp10-10607-2010, 2010.

Poisson, N., Kanakidou, M., and Crutzen, P. J.: Impact of nonmethane hydrocarbons on tropospheric chemistry and the oxidizing power of the global troposphere: 3-dimensional modelling results, J. Atmos. Chem., 36, 157-230, 2000.

Pugh, T. A. M., MacKenzie, A. R., Hewitt, C. N., Langford, B., Edwards, P. M., Furneaux, K. L., Heard, D. E., Hopkins, J. R., Jones, C. E., Karunaharan, A., Lee, J., Mills, G., Misztal, P., Moller, S., Monks, P. S., and Whalley, L. K.: Simulating atmospheric composition over a South-East Asian tropical rainforest: performance of a chemistry box model, Atmos. Chem. Phys., 10, 279-298, doi:10.5194/acp-10-279-2010, 2010.

Pugh, T. A. M., MacKenzie, A. R., Langford, B., Nemitz, E., Misztal, P. K., and Hewitt, C. N.: The influence of small-scale variations in isoprene concentrations on atmospheric chemistry over a tropical rainforest, Atmos. Chem. Phys., 11, 4121-4134, doi:10.5194/acp-11-4121-2011, 2011.

Ren, X. R., Olson, J. R., Crawford, J. H., Brune, W. H., Mao, J. Q., Long, R. B., Chen, Z., Chen, G., Avery, M. A., Sachse, G. W., Barrick, J. D., Diskin, G. S., Huey, L. G., Fried, A., Cohen, R. C., Heikes, B., Wennberg, P. O., Singh, H. B., Blake, D. R., and Shetter, R. E.: $\mathrm{HO}_{\mathrm{x}}$ chemistry during INTEX-A 2004: Observation, model calculation, and com- 
parison with previous studies, J. Geophys. Res. Atmos., 113, D05310, doi:10.1029/2007JD009166, 2008.

Salisbury, G., Rickard, A. R., Monks, P. S., Allan, B. J., Bauguitte, S., Penkett, S. A., Carslaw, N., Lewis, A. C., Creasey, D. J., Heard, D. E., Jacobs, P. J., and Lee, J. D.: Production of peroxy radicals at night via reactions of ozone and the nitrate radical in the marine boundary layer, J. Geophys. Res. Atmos., 106, 12669-12687, 2001.

Shim, C., Wang, Y. H., Choi, Y., Palmer, P. I., Abbot, D. S., and Chance, K.: Constraining global isoprene emissions with Global Ozone Monitoring Experiment (GOME) formaldehyde column measurements, J. Geophys. Res.-Atmos., 110, D24301, doi:10.1029/2004JD005629, 2005.

Sinha, V., Williams, J., Crowley, J. N., and Lelieveld, J.: The comparative reactivity method - a new tool to measure total $\mathrm{OH}$ reactivity in ambient air, Atmos. Chem. Phys., 8, 2213-2227, doi:10.5194/acp-8-2213-2008, 2008.

Stavrakou, T., Peeters, J., and Muller, J. F.: Improved global modelling of $\mathrm{HO}_{\mathrm{x}}$ recycling in isoprene oxidation: evaluation against the GABRIEL and INTEX-A aircraft campaign measurements, Atmos. Chem. Phys., 10, 9863-9878, doi:10.5194/acp-10-98632010, 2010.

Stone, D., Evans, M. J., Commane, R., Ingham, T., Floquet, C. F. A., McQuaid, J. B., Brookes, D. M., Monks, P. S., Purvis, R., Hamilton, J. F., Hopkins, J., Lee, J., Lewis, A. C., Stewart, D., Murphy, J. G., Mills, G., Oram, D., Reeves, C. E., and Heard, D. E.: $\mathrm{HO}_{\mathrm{x}}$ observations over West Africa during AMMA: impact of isoprene and $\mathrm{NO}_{\mathrm{x}}$, Atmos. Chem. Phys., 10, 9415-9429, doi:10.5194/acp-10-9415-2010, 2010.
Tan, D., Faloona, I., Simpas, J. B., Brune, W., Shepson, P. B., Couch, T. L., Sumner, A. L., Carroll, M. A., Thornberry, T., Apel, E., Riemer, D., and Stockwell, W.: $\mathrm{HO}_{\mathrm{x}}$ budgets in a deciduous forest: Results from the PROPHET summer 1998 campaign, J. Geophys. Res. Atmos., 106, 24407-24427, 2001.

Thornton, J. A., Wooldridge, P. J., Cohen, R. C., Martinez, M., Harder, H., Brune, W. H., Williams, E. J., Roberts, J. M., Fehsenfeld, F. C., Hall, S. R., Shetter, R. E., Wert, B. P., and Fried, A.: Ozone production rates as a function of $\mathrm{NO}_{\mathrm{x}}$ abundances and $\mathrm{HO}_{\mathrm{x}}$ production rates in the Nashville urban plume, J. Geophys. Res. Atmos., 107(D12), doi:10.1029/2001JD000932, 2002.

Whalley, L. K., Furneaux, K. L., Goddard, A., Lee, J. D., Mahajan, A., Oetjen, H., Read, K. A., Kaaden, N., Carpenter, L. J., Lewis, A. C., Plane, J. M. C., Saltzman, E. S., Wiedensohler, A., and Heard, D. E.: The chemistry of $\mathrm{OH}$ and $\mathrm{HO}_{2}$ radicals in the boundary layer over the tropical Atlantic Ocean, Atmos. Chem. Phys., 10, 1555-1576, doi:10.5194/acp-10-1555-2010, 2010.

Whalley, L. K.: The sensitivity of FAGE instruments to $\mathrm{RO}_{2}$ radicals, interactive comment C350-C351 on Fuchs, H., Bohn, B., Hofzumahaus, A., Holland, F., Lu, K. D., Nehr, S., Rohrer, F., and Wahner A.: Detection of $\mathrm{HO}_{2}$ by laser-induced fluorescence: calibration and interferences from $\mathrm{RO}_{2}$ radicals, Atmos. Meas. Tech., 4, 1209-1225, doi:10.5194/amt-4-1209-2011, 2011.

Wild, O., Law, K. S., McKenna, D. S., Bandy, B. J., Penkett, S. A., and Pyle, J. A.: Photochemical trajectory modeling studies of the North Atlantic region during August 1993, J. Geophys. Res.-Atmos., 101, 29269-29288, 1996. 